\title{
Table of EU/EC/EEC legislation (in chronological order)
}

Council Directive 87/54/EEC of 16

December 1986 on the legal protection of topographies of semiconductor products [1987] OJ L 24, 36-40 . .11

First Council Directive 89/104/EEC of

21 December 1988 to approximate the laws of the Member States relating to trade marks [1989] OJ L 40, 1-7 .14

Council Directive 91/250/EEC of 14 May 1991 on the legal protection of computer programs [1991] OJ L 122, 42-46 10,61

Rules of Procedure of the Court of Justice of the European Communities of 19 June 1991 [1991] OJ L 176, 7-32 .101

Council Directive 92/100/EEC of 19

November 1992 on rental right and lending right and on certain rights related to copyright in the field of intellectual property [1992] OJ L 346, 61-66 11,61

Council Directive 93/83/EEC of 27

September 1993 on the coordination of certain rules concerning copyright and rights related to copyright applicable to satellite broadcasting and cable retransmission [1993] OJ L 248, $15-21$

Council Directive 93/98/EEC of 29

October 1993 harmonising the term of protection of copyright and certain related rights [1993] OJ L

290, 9-13 10,61

Council Regulation (EC) No 40/94 of

20 December 1993 on the

Community trade mark [1994] OJ

L 11, 1-36 14

Directive 96/9/EC of the European Parliament and of the Council of 11 March 1996 on the legal protection of databases [1996] OJ

L 77, 20-28 $.5,10,61$

Directive 2001/29/EC of the European Parliament and of the Council of 22 May 2001 on the harmonisation of certain aspects of copyright and related rights in the information society [2001] OJ L 167,

$10-19$ 10,19

Directive 2001/84/EC of the European Parliament and of the Council of 27 September 2001 on the resale right for the benefit of the author of an original work of art [2001] OJ L 272, 32-36

Council Regulation (EC) No 1383/2003 of 22 July 2003 concerning customs action against goods suspected of infringing certain intellectual property rights and the measures to be taken against goods found to have infringed such rights [2003] OJ L 196, 7-14

Directive 2004/48/EC of the European Parliament and of the Council of 
29 April 2004 on the enforcement of intellectual property rights [2004] OJ L 195, 16-25 ......10, 21

Directive 2006/115/EC of the European Parliament and of the Council of 12 December 2006 on rental right and lending right and on certain rights related to copyright in the field of intellectual property (Codified version) [2006] OJ L 376, 28-35 11,142

Directive 2006/116/EC of the

European Parliament and of the Council of 12 December 2006 on the term of protection of copyright and certain related rights (Codified version) [2006] OJ L 372, 12-18 5,11

Directive 2008/95/EC of the European

Parliament and of the Council of 22 October 2008 to approximate the laws of the Member States relating to trade marks (Codified version) [2008] OJ L 299, 25-33 .14

Council Regulation (EC) No 207/2009 of 26 February 2009 on the Community trade mark (Codified version), [2009] OJ L 78, $1-42$ 14,34

Directive 2009/24/EC of the European Parliament and of the Council of 23 April 2009 on the legal protection of computer programmes (Codified version) [2009] OJ L 111, 16-22 5,10

Consolidated version of the Treaty on the European Union [2010] OJ C $83,13-44$ .13
Consolidated version of the Treaty on the functioning of the European Union [2010] OJ C 83, 47-199

Directive 2011/77/EU of the European Parliament and of the Council of 27 September 2011 amending Directive 2006/116 on the term of protection of copyright and certain related rights [2011] OJ L 265, $1-5$ 11,50

Regulation (EU) No 386/2012 of the European Parliament and of the Council of 19 April 2012 on entrusting the Office for Harmonization in the Internal Market (Trade Marks and Designs) with task related to the enforcement of intellectual property rights including the assembling of public and private-sector representatives as a European Observatory on Infringements of Intellectual Property Rights [2012] OJ L 129, 1-6 ...........................................34

Proposal for a Directive of the European Parliament and of the Council on collective management of copyright and related rights and multi-territorial licensing of rights, in musical works for online uses in the internal market, Brussels, 11 July 2012, COM (2012) 372 final, 2012/0180 (COD) 38,234

Directive 2012/28/EU of the European Parliament and of the Council of 25 October 2012 on certain permitted uses of orphan works, [2012] OJ L 2995, 5-12 ......11, 38 